\title{
Comment on Eimer and Senter
}

ROBERT BOICE AND WAYNE P. ASPEY, DEPARTMENT OF PSYCHOLOGY, OHIO UNIVERSITY, Athens, Ohio 45701

Eimer \& Senter (1968) seem to equate their "wild rats" (pack rats) with the "fierce, aggressive" wild Norway rats used by Richter (1957). In extensive work with four species of Neotoma we have found pack rats far less fierce and aggressive (e.g., easier to handle) than wild Norway rats. More important, pack rats have greater fluid intake needs than Norway rats (Schmidt-Nielsen, 1964). Although pack rats generally weigh less than Norway rats, the water intake of the former may be twice that of the latter (Boice, 1967). Thus Eimer and Senter's conclusion that greater alcohol intake in domestic Norway rats. . " is not surprising since the domestic rats were heavier than were the wild rats"... (p. 319) does not follow from previous research.

Eimer and Senter also not that... "wild rats in contrast to domestic rats have large adrenal glands" (p. 320). This interpretation of drinking behavior in pack rats is indeed "tentative"

Table 1 Adrenal Weights

\begin{tabular}{lccc} 
Species & $\mathrm{N}$ & $\begin{array}{c}\text { Mean of both } \\
\text { adrenals }(\mathrm{g})\end{array}$ & $\begin{array}{c}\text { Mean body } \\
\text { weight }(\mathrm{g})\end{array}$ \\
\hline $\begin{array}{l}R . \text { norvegicus } \\
\text { (albino) }\end{array}$ & 4 & 0.020 & 375.6 \\
$\begin{array}{l}R . \text { norvegicus } \\
\quad \text { brown domestic) }\end{array}$ & 4 & 0.033 & 330.9 \\
$\begin{array}{l}R . \text { norvegicus } \\
\quad \text { (wild) }\end{array}$ & 4 & 0.049 & 311.8 \\
\begin{tabular}{l} 
N. floridana \\
\hline
\end{tabular} & 2 & 0.025 & 270.1 \\
\hline
\end{tabular}

since it is apparently based on research with Norway rats (e.g., Robinson, 1965). Adrenals from our two most fierce and aggressive pack rats (Neotoma floridana) are more similar in size per body weight to domestic than to wild Norway rats (Table 1). Perhaps Eimer and Senter are referring to adrenal size relative to that of domestic pack rats. Pack rats, however, are not commonly bred in the laboratory (Ecosque, 1957).

It would seem that Eimer and Senter's aim to. . "investigate more systematically the observation made by Richter" (p. 319). . . would be better accomplished with wild Norway rats. Wild Norway rats are actually easier to capture than pack rats. Trap placements in an active land-fill where the Norway rats are not neophobic usually results in a capture within $15 \mathrm{~min}$. Of a variety of rodents tested in our laboratory, incidentally, we have had most success in inducing wood chucks (Marmota monax) to ingest alcoholic beverages.

\section{REFERENCES}

BOICE, R. Lick rates and topographies as taxonomic criteria in southwestern rodents. Psychon. Sci., 1967, 9, 431-432.

EIMER, E. O., \& SENTER, R. J. Alcohol consumption in domestic and wild rats. Psychon. Sci, 1968, 10, 319-320.

ECOSQUE, H. J. The desert woodrat: a laboratory colony. J. Mammal., 1957, 38, 472-481.

woodrat: a laboratory colony. J. Mammal., 1957, 38, 472-481.

ROBINSON, R. Genetics of the Nomay' rat. Oxford: Pergamon Press, 1965. RICHTER. C. P. Decreased appetite for alcohol and alcoholic beverages produced in rats by thyroid treatment. In H. Hoagland (Ed.). Hormone's. brain function and behavior. New York: Academic Press. 1957. Pp. 217-220.

SCHMIDT-NIELSEN, K. Desert animals. New York: Oxford. 1964. 